\title{
Immunobiochemical Characteristics of Purified Native Leptin Protein from Indian Major Carp, Rohu (Labeo rohita Ham.)
}

\author{
Seikh Sahanawaz Alam ${ }^{1,2}$, Siddhartha Narayan Joardar ${ }^{1 *}$, Ashis Kumar Panigrahi², \\ Thangapalam Jawahar Abraham ${ }^{3}$, Sabyasachi Mukherjee ${ }^{4}$, Anupama Mukherjee ${ }^{4}$ \\ ${ }^{1}$ Department of Veterinary Microbiology, West Bengal University of Animal and Fishery Sciences, \\ Kolkata, India \\ ${ }^{2}$ Department of Zoology, University of Kalyani, Kalyani, India \\ ${ }^{3}$ Department of Aquatic Animal Health, West Bengal University of Animal and Fishery Sciences, Kolkata, India \\ ${ }^{4}$ National Research Centre on Mithun, Indian Council of Agricultural Research, Jharnapani, Medziphema, India \\ Email: *joardar69@gmail.com
}

Received 24 September 2014; revised 24 October 2014; accepted 11 November 2014

Copyright (C) 2014 by authors and Scientific Research Publishing Inc.

This work is licensed under the Creative Commons Attribution International License (CC BY). http://creativecommons.org/licenses/by/4.0/

cc) (i)

Open Access

\begin{abstract}
Information regarding molecular characteristics of leptin protein in different animal species including fish is scarce. With the aim of characterizing the native leptin protein of Indian major carprohu (Labeo rohita), at molecular level, the present study was designed to isolate rohu leptin from its hepatocytes (the prime source of leptin in fish) and immunobiochemical characterization of the same, subsequently. In the present study, chemical treatment and ultra-sonication technique was used for isolating leptin from rohu liver tissue. Purification of the protein was attempted using affinity column chromatography. The molecular, biophysical and serological characterization of rohu leptin was carried out by 2D-gel electrophoreis, SDS-PAGE, MALDI-TOF Mass spectroscopy and Western blot. The SDS-PAGE and 2D gel analysis revealed that rohu native leptin possesses molecular mass of $16 \mathrm{kDa}$. Western blot analysis showed that the fish hepatocytes possessed the seroreactive leptin protein of $16 \mathrm{kDa}$. MALDI-TOF mass spectroscopy and peptide analysis showed the molecular mass of rohu leptin as $16283.38 \mathrm{Da}$. The serodiagnostic potential of native leptin of rohu was revealed for the first time while assessing its serological responses by ELISA using antileptin antibodies.
\end{abstract}

\section{Keywords}

Affinity Chromatography, ELISA, Leptin, MALDI-TOF, Rohu, Western Blot

\footnotetext{
${ }^{*}$ Corresponding author.
}

How to cite this paper: Alam, S.S., Joardar, S.N., Panigrahi, A.K., Abraham, T.J., Mukherjee, S. and Mukherjee, A. (2014) Immunobiochemical Characteristics of Purified Native Leptin Protein from Indian Major Carp, Rohu (Labeo rohita Ham.). Open Journal of Immunology, 4, 139-147. http://dx.doi.org/10.4236/oji.2014.44016 


\section{Introduction}

Leptin is a $16 \mathrm{kDa}$ adipocyte-derived cytokine like protein hormone composed of 167 amino acid residues produced mainly by adipose tissue and, at a lower extent, by other organs such as stomach, placenta, muscle, immune cells and mammary gland [1]. It has been discovered in rodents where it is a synthesized primarily in adipose tissue and released into the blood stream [2]. The role of leptin as a lipostatic signal regulating whole body energy metabolism makes it one of the best physiological markers for body weight (BW), food intake, energy expenditure and reproduction. Circulating leptin and adipose tissue leptin-mRNA levels are correlated with BW, feed intake, nutritional status, and adipose tissue mass in human and animals [3] [4]. Rohu, Labeo rohita, is one of the most popular Indian major carps of the Indian subcontinent and considered precious among sweet water fish and hence a symbol of world biodiversity conservation. It is needless to mention that without proper breeding strategies this precious animal can not be preserved for long in pure form. Selection of animal for breeding purpose on the basis of leptin production and secretion might be a useful strategy in terms of better growth, body weight and reproductive ability. Circulating concentrations of leptin may provide an indicator of fat content in live animals and thus facilitate more appropriate feeding and marketing strategies [5]. However, this important protein has not been studied and characterized in fish till date. Although extensive studies have been done on leptin of human and laboratory animals, information in aquatic animals is scarce. With the aim of characterizing the fish leptin at molecular level, the present study was designed to isolate and purify rohu leptin protein with its subsequent molecular and serological characterization. The present communication reveals for the first time the sero-diagnostic potential of fish leptin that might be exploited while preparing of sero-diagnostic tool(s) for fish leptin detection from unknown (test) samples and/or measuring leptin concentration in blood, needed to select specific (individual) animal(s) for breeding purposes.

\section{Materials and Methods}

\subsection{Isolation of Fish Leptin}

Liver tissue was collected from rohu (Labeo rohita) and kept in deep freezer $\left(-20^{\circ} \mathrm{C}\right)$ till used. Isolation of fish leptin was carried out as per Peinado et al. [6]. In brief, the rohu liver (1 gm) collected was thawed in $0.4 \mathrm{ml}$ of cold Urea/thiourea buffer (7 M urea, 2 M thiourea, 4\% CHAPS, $45 \mathrm{mM}$ Tris, $\mathrm{pH}$ 7.4, $60 \mathrm{mM}$ DTT) and complete protease inhibitors (one tablet/20 ml, Roche, Barcelona, Spain) supplemented with $0.1 \mathrm{mM} \mathrm{NaCl}$. Hepatocytes were mechanically disrupted and briefly sonicated (Hielscher Ultrasonics GmBH, Germany). Samples were adjusted to $900 \mu \mathrm{l}$ with lysis buffer ( $20 \mathrm{mM}$ Tris, $\mathrm{pH} 7.4 ; 100 \mathrm{mM} \mathrm{NaCl} ; 1 \%$ Triton and protease inhibitors) and incubated for $15 \mathrm{~min}$ at $35^{\circ} \mathrm{C}$. After cooling on ice (10 min), $100 \mu \mathrm{l}$ of $0.1 \mathrm{M}$ Tris, $\mathrm{pH}$ 7, and $50 \mathrm{mM} \mathrm{MgCl}_{2}$ were added to the homogenate, which were then incubated with DNase-1 (30 U Sigma) on ice (10 min). The homogenate was centrifuged for $15 \mathrm{~min}$ at $10,000 \mathrm{~g}\left(4^{\circ} \mathrm{C}\right)$ and the aqueous phase between the upper lipid phase and the lower cellular debris phase was collected. Finally, the extract was separated by chloroform/methanol precipitation and dissolved in phosphate buffer solution (pH-7.4). The total protein concentration was determined using Lowry's method [7].

\subsection{Isoelectric Focusing and Two Dimensional-Polyacrylamide Gel Electrophoresis (2D-PAGE)}

Isoelectric focusing and 2D-PAGE of proteins obtained from chemically treated fish liver tissue was performed as per Peinado et al. [6]. Hepatocyte protein was treated with $0.2 \mathrm{ml}$ rehydration buffer (8 M urea, 2\% CHAPS, 50 mM DTT, 0.2\% ampholytes pH 3 - 10 and 0.002\% bromophenol blue). Electrophoresis was carried out following the manufacturer's protocol (Bio-Rad Laboratories, USA). Briefly, non linear pH 3 - 10 IPG strip was rehydrated with $0.25 \mathrm{ml}$ rehydration buffer containing $0.05 \mathrm{ml}$ sample overnight at $25^{\circ} \mathrm{C}$ and then subjected to isoelectric focusing. The strip was then equilibrated with reducing buffer (6 M urea, 2\% SDS, 30\% glycerol, 50 $\mathrm{mM}$ Tris-HCl and $25 \mathrm{mM}$ DTT) followed by alkylation buffer (6 M urea, 2\% SDS, 30\% glycerol, $50 \mathrm{mM}$ Tris$\mathrm{HCl}$ and $135 \mathrm{mM}$ IAA). The strip was then placed on $12.5 \%$ SDS polyacrylamide gel using $1 \%$ agarose in SDSPAGE running buffer. After electrophoresis gels were stained by SYPRO Rubi dye (Bio Rad Laboratories, USA). The stained gel was washed with washing solution ( $10 \%$ methanol, $7 \%$ glacial acetic acid) and the final washing was done with Milli-Q water for 10 min according to manufacturer's instructions. Gel was scanned with the help of Fuji scanner in the fluorescence mode to visualize the stained gel. The spot volume was meas- 
ured and reported as percent volume of the spot (normalized volume of spots, \% volume) in relation to the sum of all detected spot and this provided normalized spot volume. The change in \% volume is the basis of detection of differential protein identification.

\subsection{Purification of Rohu Leptin by Affinity Column Chromatography}

Leptin being glycoprotein, purification of native rohu leptin was attempted using affinity chromatography kit (Genei, India) having Concavalin-A (Con-A) attached with carbon background (cellulose). In the first step, ConA agarose column was prepared in sodium acetate buffer as per manufacture's instruction. Then the sample protein was charged on the column and the unbound fraction was eluted with sodium acetate buffer. In next step, bound fraction was eluted with the help of elution buffer. The fractionated proteins (Con-A bound) were pooled and dialyzed against distilled water at $4{ }^{\circ} \mathrm{C}$. The collected protein pool was concentrated by sucrose, sterilized through a membrane filter $(0.22 \mu)$, and stored at $-20^{\circ} \mathrm{C}$. The protein concentration of the obtained fractionated protein was estimated by Lowry’s method [7].

\subsection{SDS-PAGE}

Crude and affinity fractionated rohu hepatocyte proteins were analyzed by sodium dodecyl sulphate polyacrylamide electrophoresis (SDS-PAGE) as per Laemmli [8] using 12.5\% polyacrylamide gel in a vertical slab gel electrophoretic apparatus (Attao, Japan). The samples were mixed with sample buffer in a proportion of 1:1 and subsequently the solution was heated at $100^{\circ} \mathrm{C}$ for $3 \mathrm{~min}$. The amount of protein applied was $50 \mu \mathrm{g}$ per track. Proteins were run at $18 \mathrm{~mA}$ for $150 \mathrm{~min}$. The bands were visualized by staining with monochromatic silver staining [9]. Standard medium range molecular weight marker (PMW-M, Genei, India) was run parallel along with sample proteins to determine the molecular mass of the polypeptides.

\subsection{Preparation of Antiserum}

Hyperimmune serum, against the affinity fractionated rohu hepatocyte protein, was raised in rabbit as per Mishra et al. [10] with some modifications that encompass increased doses. Briefly, two New Zealand White (NZW) male rabbits weighing 1200 g were injected intramuscularly with 5 doses of affinity purified antigen, mixed with equal volume of Freund's adjuvant (Sigma, USA) at 10 days interval with increased subsequent doses ranging from $600 \mu \mathrm{g}$ to $1200 \mu \mathrm{g}$ per injection. First dose was given with Freund's complete adjuvant (FCA) and subsequent 4 doses with Freund's incomplete adjuvant (IFA). One rabbit of same breed, sex and weight was also maintained without immunisation to collect normal serum.

\subsection{Agar Gel Precipitation Test (AGPT)}

The seroreactivity of affinity fractionated hepatocyte protein and titre of the antiserum were assessed by AGPT as per Ouchterlony [11].

\subsection{Western Blot Analysis}

Affinity fractionated leptin protein was separated on a 12.5\% gel (SDS-PAGE), and electro transferred onto nitrocellulose membrane using a semi dry blotting unit (Atto, Japan) as per Towbin et al. [12]. The blotted proteins were subjected to immunoblot analysis using hyper immune serum raised in rabbit (polyclonal antibodies) and anti-rabbit horse radish peroxidase (HRPO) immunoconjugate (Genei, India). Standard molecular weight marker (Fermentas) was run parallel along with sample proteins to determine the relative molecular weights of the polypeptides.

\subsection{MALDI-TOF Mass Spectrometry}

The molecular mass of affinity fractionated rohu hepatocyte protein was determined by Voyager DE Pro ${ }^{\mathrm{TM}}$ mass spectrometer equipped with $337 \mathrm{~nm} \mathrm{~N}$ laser (Applied Biosystems, USA) as per Mandal et al. [13]. The sample protein $(2 \mu \mathrm{l})$ was mixed with MALDI matrix, synapinic acid $(8 \mu \mathrm{l})$, then $2 \mu \mathrm{l}$ of mixture solution was spotted onto the MALDI 100 well stainless steel sample plate and allowed to air dry (for 5 hr) prior to the MALDI analysis. The spectra were recorded in the positive ion linear mode in accelerating voltage $20 \mathrm{kV}$. Peptide mono- 
isotopic mass was obtained in linear mode with external calibration. It was performed using calibration mixture 1 (Applied Biosystems, USA) having Arg1-Bradykinin (m/z, 904.468), angiotensin I (m/z, 1296.685), Glu1-fibrinopeptide B (m/z, 1570.677) and ACTH (18 - 39) (m/z, 2465.199). Reproducibility of the spectrum was checked 5 times from separately spotted samples.

\subsection{Enzyme Linked Immunosorbent Assay (ELISA)}

Dip-stick ELISA was performed with the affinity fractionated protein following the procedure of Jiahao et al. [14] with some modifications in substrate buffer composition. Coating of two sticks was done by affinity fractionated protein @ $2 \mu \mathrm{g} / \mathrm{srip}$. After blocking and subsequent washing of the sticks, hyperimmune and normal serum were added in the sticks, respectively. In the next step, after proper washing, anti-rabbit HRPO conjugate (Genei, India) was added to the sticks. The colour development step was carried out by dipping the sticks into substrate solution (40 $\mathrm{ml} \mathrm{H}_{2} \mathrm{O}_{2}, 0.025$ gm diaminobenzydine in $10 \mathrm{ml}$ Tris $\mathrm{HCl}, \mathrm{pH}$ 7.5).

Using known concentration of affinity fractionated protein, a plate ELISA was standardized based on sandwich ELISA principle. Blood was collected from apparently healthy rohu $(n=24)$, serum separated and used as unknown sample for detection of leptin concentration using the standardized protocol developed. The concentration (ng/ml) of each unknown sample was extrapolated by putting the O.D. values in the standard graph prepared from the known concentrations (5 ng/ml through $160 \mathrm{ng} / \mathrm{ml}$ ).

\section{Results}

\subsection{Estimation of Protein Concentration}

The concentration of the crude protein from hepatocyte tissue of rohu was observed as $6.2 \mathrm{mg} / \mathrm{ml}$ and affinity fractionated protein was found to be $0.15 \mathrm{mg} / \mathrm{ml}$

\subsection{Isoelectric Focusing and 2D-PAGE}

Two Dimensional Gel electrophoresis of crude hepatocyte protein after processing showed several proteins in the range of molecular weight $3-97.4 \mathrm{kDa}$. The proteins were mainly present in 4 - 8 pI range. In the sample, proteins of low and high molecular weight were less abundant. Proteins were mainly visible in the range of 6 $70 \mathrm{kDa}$ range (Figure 1).

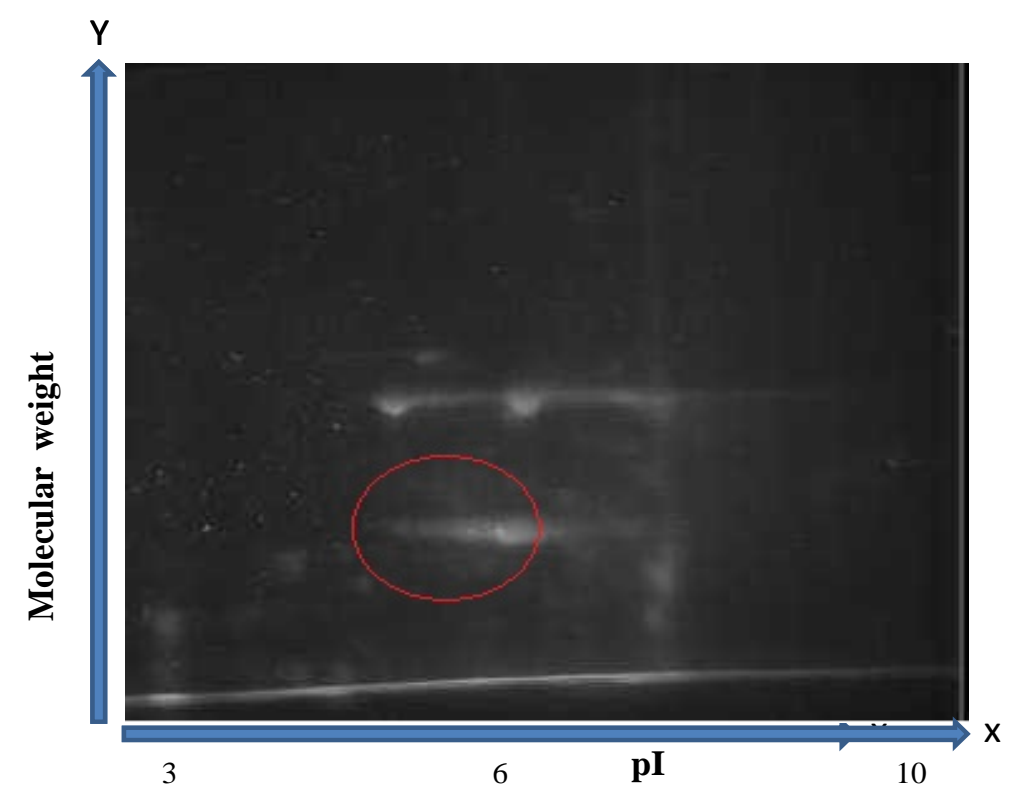

Figure 1. 2D-gel electrophoresis of rohu hepatocyte proteins. X-axis represents pI range 3 - 10 where $\mathrm{Y}$-axis represents molecular weight of 3.5 - 205 kDa range. 


\subsection{SDS-PAGE}

When the crude protein obtained from liver tissue was subjected to SDS-PAGE analysis, 25 (twenty-five) polypeptides in the molecular weight range 3 to $130 \mathrm{kDa}$ were obtained. The affinity bound fraction yielded only four polypeptides of which one (16 kDa) was major and three (4.7 and $54 \mathrm{kDa})$ were minor (Figure 2).

\subsection{Agar Gel Precipitation Test}

The specificity between fractionated protein and hyperimmune serum was indicated by clear band between the wells. The titre of the hyperimmune serum was found as 4 . (Result not shown)

\subsection{Western Blot Analysis}

When western blot analysis was performed with the affinity fractionated protein using polyclonal antibodies, a band corresponding to $16 \mathrm{kDa}$ was observed indicating the presence of $16 \mathrm{kDa}$ leptin protein in the affinity fractionated sample (Figure 3).

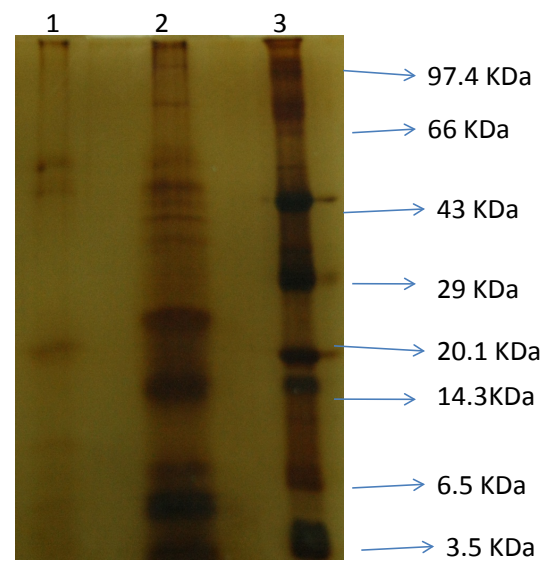

Figure 2. Polypeptide profile of crude and affinity fractionated proteins of hepatocytes obtained from rohu as assessed by SDS-PAGE. Lane 1: Affinity fractionated protein; Lane 2: Crude liver protein; Lane 3: Standard protein molecular weight marker (medium range).

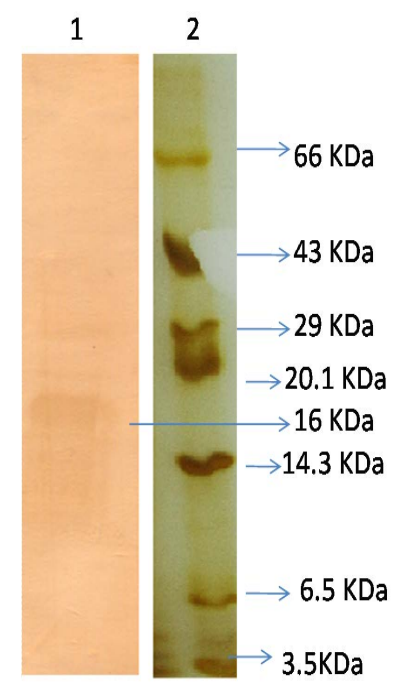

Figure 3. Western blot analysis of affinity purified leptin obtained from liver tissue of rohu Lane 1: Affinity purified leptin. Lane 2: Standard Molecular weight marker range ( $3.5 \mathrm{kDa}$ to $205 \mathrm{kDa}$ ). 


\subsection{MALDI-TOF Mass Spectrometry}

The affinity fractionated protein when subjected to MALDI-TOF mass spectrometry to determine the molecular mass more precisely, one of the constituent proteins revealed as 16283.38 Da (Figure 4).

\subsection{ELISA}

Affinity fractionated rohu hepatocyte protein was further used in dip-stick ELISA to ascertain its sero-diagnostic potentiality. The difference in intensity of developed colour between hyperimmune and normal serum is shown in Figure 5. Out of the two dip-sticks used, the first stick showed strong seroreactivity.

The O.D. values of unknown serum samples ranged from 0.672 to 0.903 . When the individual values $(n=24)$ were used for determining leptin concentration from the standard graph (Figure 6), the concentration varied between 38 to $72 \mathrm{ng} / \mathrm{ml}$.

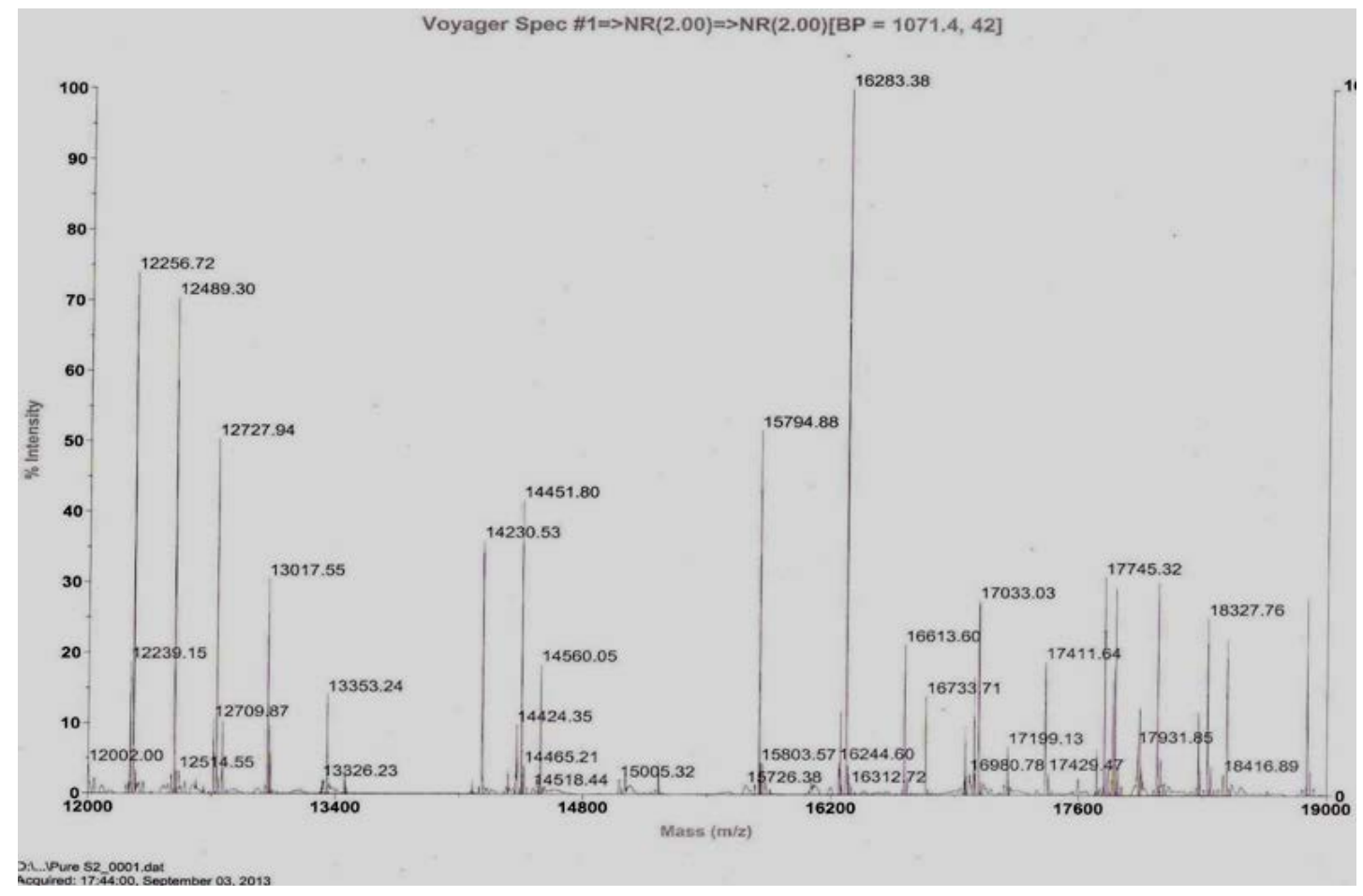

Figure 4. MALDI-TOF Mass spectrometry of rohu native leptin.

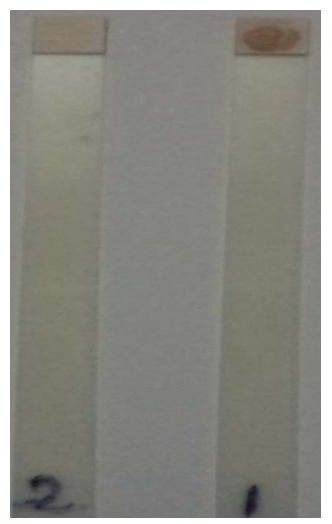

Figure 5. Sero-reactivity of rohu leptin with antiserum and control serum as assessed by Dipstick ELISA. Dipstick 1: Anti-leptin antibody (hyperimmune serum); Dipstick 2: control (normal serum). 


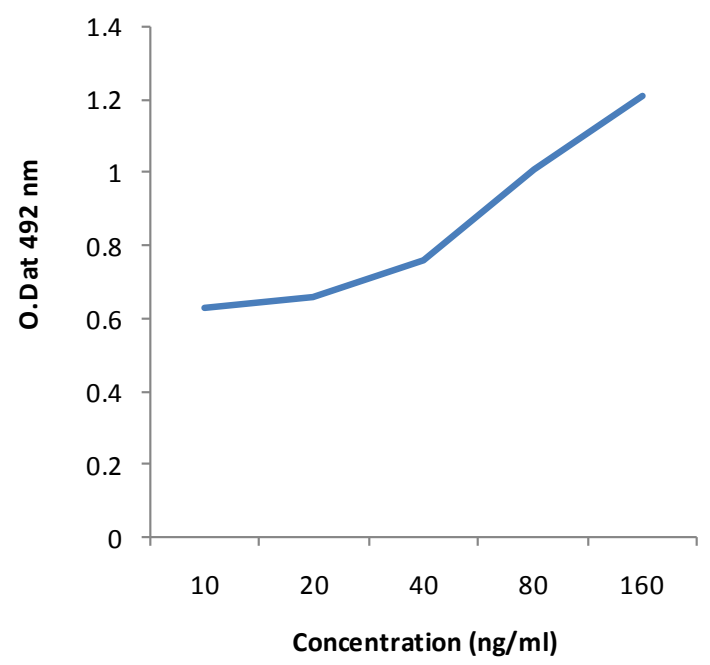

Figure 6. Standard graph prepared for determining leptin concentration in unknown serum samples of rohu.

\section{Discussion}

Leptin is a protein hormone synthesized and secreted primarily by adipocytes of mammals in response to increased energy storage in adipose tissue [2] [15]. White adipose tissue is the key site of leptin production in mammals [16]. In the present study, rohu (Labeo rohita) liver tissue was considered for leptin protein isolation. After chemical treatment followed by ultra-sonication, crude proteins were obtained from hepatocytes. Then, the crude proteins were subjected to 2D-gel electrophoresis for assessing protein profile of rohu hepatocyte. The molecular weight and isoelectric point (pI) are the two important parameters generally used for identification of desired protein [6]. In the present work, the polypeptide profile of the crude proteins of liver tissue origin contained low and high molecular weight polypeptides in the range of $3 \mathrm{kDa}$ to $130 \mathrm{kDa}$ including proteins of 16 $18 \mathrm{kDa}$. The 2D-gel electrophoresis of crude protein showed the presence of several proteins with various sizes and isoelectric points (pI) in the range of 5.2 - 6.8 and molecular weight $15-20 \mathrm{kDa}$. As pI of leptin protein of mammals is 5.8 [17], the possibility of presence of leptin protein in this preparation was inevitable. In the next step, affinity purification of the crude protein was done using ConA-celllulose column. The affinity purified protein revealed a major band of molecular mass $16 \mathrm{kDa}$ along with three minor bands of 4.7 and $54 \mathrm{kDa}$ as assessed by SDS-PAGE. It showed that the affinity chromatographed fraction was a semi-purified preparation having a major protein of molecular mass $16 \mathrm{kDa}$. The present work corroborates with the previous work of Cohen and co-workers where the molecular mass of affinity purified recombinant human leptin protein was estimated as approximately 16,000 Da by SDS-PAGE while the molecular mass of endogenous human leptin was reported as $16.026 \pm 9$ Da by MALDI mass technique [4]. The molecular weight of leptin protein was reported earlier within the range of 16 - $18 \mathrm{kDa}$ [18] [19]. Recently, the molecular mass of native leptin from goat was found to be of $16 \mathrm{kDa}$ by SDS-PAGE [20]. In the present study, western blot analysis revealed that rohu adipocytes contained the leptin $(16 \mathrm{kDa})$ protein in affinity chromatographed bound fraction having seroreactive property. Earlier, western blot analysis with leptin-specific antibody detected a protein with a molecular mass of approximately 15 - $16 \mathrm{kDa}$ in dunlin liver and adipose tissue [21]. The actual molecular mass of leptin protein of fish (rohu) was carried out using mass spectroscopic analysis and the molecular weight obtained was 16283.38 $\mathrm{Da}$. In a previous study, gel pieces containing the leptin protein $(16-\mathrm{kDa})$ of giant panda were excised and their peptide mass fingerprints were obtained and analyzed by MALDI TOF-TOF-MS. The mass of the mature protein without the signal peptides was detected as $16.8 \mathrm{kDa}$ [22]. Recently in our laboratory, MALDI-TOF mass spectroscopy was used to determine actual molecular mass of native goat leptin. It was found as $15948.72 \mathrm{Da}$ [20]. The sero-reactivity of affinity purified fraction was confirmed by dipstick ELISA with the help of anti-fish leptin antibodies. Subsequently, one plate ELISA protocol was standardized to determine the concentration of unknown rohu samples $(n=24)$. The leptin concentration in unknown rohu serum samples were in the range of 38 to $72 \mathrm{ng} / \mathrm{ml}$. This value differed from earlier observations of mammals (mean value $6.0 \mathrm{ng} / \mathrm{ml}$ in sheep, ranging between 0.3 to $13.8 \mathrm{ng} / \mathrm{ml}$ in dog) using plate ELISA [23] [24]. Present study revealed potentiality of 
ELISA in detecting fish leptin in clinical (suspected/unknown) samples and thus explored the possibility of replacing other prevalent serodiagnostic assay viz. radioimmunoassay.

\section{Conclusion}

In short, it may be concluded that column chromatography may be used to purify native leptin from fish (Labeo rohita). Moreover, fish leptin possesses a molecular mass of $16283.38 \mathrm{Da}$ and also sero-reactive property that might be exploited while preparing of sero-diagnostic tool(s) for detecting leptin in clinical samples and/or measuring leptin concentration in blood that might be needed to select specific fish for selective breeding purpose. Further, as cross reactivity exists (due to structural similarity) between mammalian and fish leptin, rohu leptin being cheap and easily available source can be exploited in clinical detection system (e.g. ELISA) of mammalian (even human) leptin. Commercially available anti-goat leptin antibody could detect rohu leptin in ELISA (result not shown), indicating its (rohu leptin) diagnostic potentiality in mammalian system.

\section{Acknowledgements}

The work was supported by the grant (BT/01/NE/TBP/2010) of Twinning Programme for NE, sponsored by The Department of Biotechnology, Government of India, New Delhi. Authors are thankful to the Vice Chancellor, West Bengal University of Animal and Fishery Sciences, Kolkata and the Director, Indian Institute of Technology, Kharagpur for providing necessary infrastructure facilities.

\section{References}

[1] Ahima, R.S. and Filer, J.S. (2000) Leptin and the Neuroendocrinology of Fasting. Annual Reviews of Physiology, 62, 413-437. http://dx.doi.org/10.1146/annurev.physiol.62.1.413

[2] Zhang, Y., Proenca, R., Maffei, M., Barone, M., Leopoid, L. and Friedman, J.M. (1994) Positional Cloning of the Mouse Obese Gene and Its Human Homologue. Nature, 372, 425-432. http://dx.doi.org/10.1038/372425a0

[3] McGregor, G.P., Desaga, J.F., Ehlenz, K., Fischer, A., Heese, F., Hegele, A., Lammer, C., Peiser, C. and Lang, R.E. (1996) Radio Immunological Measurement of Leptin in Plasma of Obese and Diabetic Human Subjects. Endocrinology, 137, 1501-1504.

[4] Cohen, S.L., Halass, J.L., Friedman, J.M., Chait, B.T., Bennett, L., Chang, D., Hecht, R. and Collins, F. (1996) Human leptin Characterization. Nature, 382, 15-20. http://dx.doi.org/10.1038/382589a0

[5] Geary, T.W., McFadin, E.L., MacNeil, M.D., Grings, E.E., Short, R.E., Funston, R.N. and Keisler, D.H. (2003) Leptin as a Predictor of Carcass Composition in Brief Cattle. Journal of Animal Sciences, 81, 1-8.

[6] Peinado, J.R., Jimenez-Gomez, Y., Pulido, M., Ortega-Bellido, M., Diaz-Lopez, C., Padillo, J.F., Lopez-Miranda, J., Vazquez-Martínez, R. and Malagon, M. (2010) The Stromal-Vascular Fraction of Adipose Tissue Contributes to Major Differences between Subcutaneous and Visceral Fat Depots. Proteomics, 10, 3356-3366. http://dx.doi.org/10.1002/pmic.201000350

[7] Lowry, O.H., Rosenbrough, N.J., Farr, A.L. and Randall, R.J. (1951) Protein Measurement with Folin-Phenol Reagent. Journal of Biological Chemistry, 193, 265-275.

[8] Laemmli, U.K. (1970) Cleavage of Structural Proteins during Assembly of the Head of Bacteriphage T . Nature, 227, 680-685. http://dx.doi.org/10.1038/227680a0

[9] Shevchenko, A., Wilm, M., Vorm, O. and Mann, M. (1996) Mass Spectrometric Sequencing of Proteins from Silver-Stained Polyacrylamide Gels. Annals of Chemistry, 68, 850-858. http://dx.doi.org/10.1021/ac950914h

[10] Mishra, S.S. and Sekhar, M.S. (1997) ELISA and Dot Immunoassay for Detection of Vibrio spp. in Tiger Shrimp Penaeus monodon. Indian Journal of Fisheries, 44, 369-376.

[11] Ouchterlony, O. (1953) Antigen-Antibody Reactions in Gels. IV. Types of Reactions in Coordinated Systems of Diffusion. Acta Pathologica et Microbiologica Scandinavica, 32, 231-240. http://dx.doi.org/10.1111/j.1699-0463.1953.tb00247.x

[12] Towbin, H., Staehelin, T. and Gorden, J. (1979) Electrophoretic Transfer of Proteins from Polyacrylamide Gels to Nitrocellulose Sheets: Procedure and Some Applications. Proceedings of National Academy of Science of USA, 76, 4350-4354. http://dx.doi.org/10.1073/pnas.76.9.4350

[13] Mandal, S.M., Dey, S., Mandal, M., Neto, S.M. and Franco, O.L. (2009) Identification and Structural Insights of Three Novel Antimicrobial Peptides Isolated from Green Coconut Water. Peptides, 30, 633-637.

http://dx.doi.org/10.1016/j.peptides.2008.12.001 
[14] Jiahao, M., Xueqin, L., Zhenyin, W., Zhenguo, Y. and Wendong, W. (1997) Rapid Detection of Motile Aeromonas Species in Fish by Dot ELISA. Journal of Dalian Fisheries College, 12, 72-78.

[15] Halaas, J.L., Gajiwala, K.S., Maffei, M., Cohen, S.L. and Friedma, J.M. (1995) Weight Reducing Effects of the Plasma Protein Encoded by the Obese Gene. Science, 269, 543-546. http://dx.doi.org/10.1126/science.7624777

[16] Cinti, S., Frederich, R.C., Zingaretti, M.C., De Matteis, R., Flier, J.S. and Lowell, B.B. (1997) Immunohistochemical Localization of Leptin Uncoupling Protein in White and Brown Tissue. Endocrinology, 138, 797-804.

[17] DiMarchi, R.D., Hermeling, R.N. and Hoffmann, J.A. (1998) Anti-Obesity Proteins. US Patent 5,7,19,266.

[18] Takahashi, N., Patel, H.R., Qi, Y., Dushay, J. and Ahima, R.S. (2002) Divergent Effects of Leptin in Mice Susceptible or Resistant to Obesity. Hormone Metabolism Research, 34, 691-697. http://dx.doi.org/10.1055/s-2002-38251

[19] Taniguchi, Y., Itoh, T., Yamada, T. and Sasaki, Y. (2002) Genomic Structure and Promoter Analysis of the Bovine Leptin Gene. IUBMB Life, 53, 131-135. http://dx.doi.org/10.1080/15216540211465

[20] Alam, S.S., Joardar, S.N. and Panigrahi, A. (2014) Immunobiochemical Characterization of Native Leptin from Goat (Capra hircus): Serodiagnostic Potentiality Revealed. Advances in Veterinary and Animal Sciences, 2, 86-90. http://dx.doi.org/10.14737/journal.aavs/2014/2.2.86.90

[21] Kochan, Z., Karbowska, J. and Meissner, W. (2006) Leptin Is Synthesized in the Liver and Adipose Tissue of the Dunlin (Calidris alpina). General and Comparative Endocrinology, 148, 336-339. http://dx.doi.org/10.1016/j.ygcen.2006.04.004

[22] Xu.,Q., Xinming, Z., Ning, H., Jianxin, S., Rong, H., Zhihe, Z., Hongwu, B. and Muyuan, Z. (2010) Characterization and Expression of Ailuropoda melanoleuca Leptin (ob Gene). Zoological Science, 27, 41-46. http://dx.doi.org/10.2108/zsj.27.41

[23] Kauter, K., Bal, M., Kearney, P., Tellam, R. and McFarlane, J.R. (2000) Adrenaline, Insulin and Glucagon Do Not Have Acute Effects on Plasma Leptin Levels in Sheep: Development and Characterisation of an Ovine Leptin ELISA. Journal of Endrocrinology, 166, 127-135. http://dx.doi.org/10.1677/joe.0.1660127

[24] Shibata, H., Akahane, R., Honjoh, T., Asano, M., Mominoki, K., Fujii, K., Suzuki, M., Ohtashi, N., Ishioka, K., Ahmed, M., Soliman, M., Kimura, K. and Saito, M. (2005) Seasonal Changes in Serum Leptin of the Feral Raccoon (Procyon lotor) Determined by Canine-Leptin-Specific ELISA. Journal of Experimental Zoology, 303A, 527-533. http://dx.doi.org/10.1002/jez.a.185 
Scientific Research Publishing (SCIRP) is one of the largest Open Access journal publishers. It is currently publishing more than 200 open access, online, peer-reviewed journals covering a wide range of academic disciplines. SCIRP serves the worldwide academic communities and contributes to the progress and application of science with its publication.

Other selected journals from SCIRP are listed as below. Submit your manuscript to us via either submit@scirp.org or Online Submission Portal.
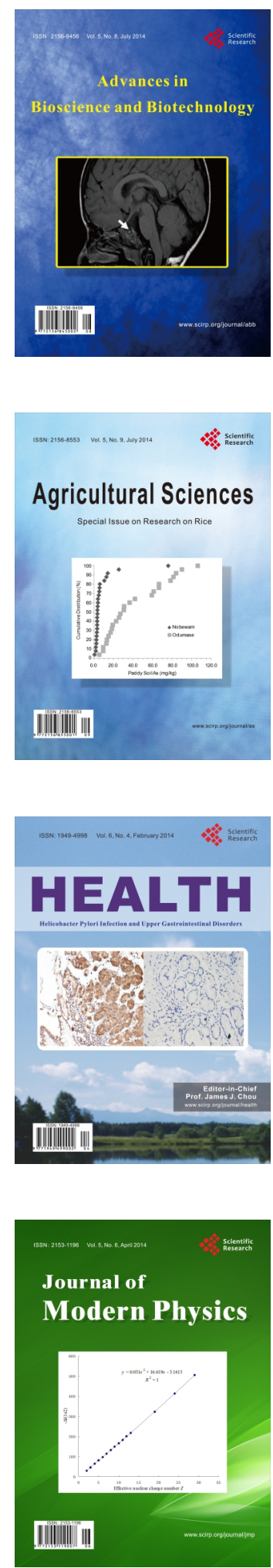
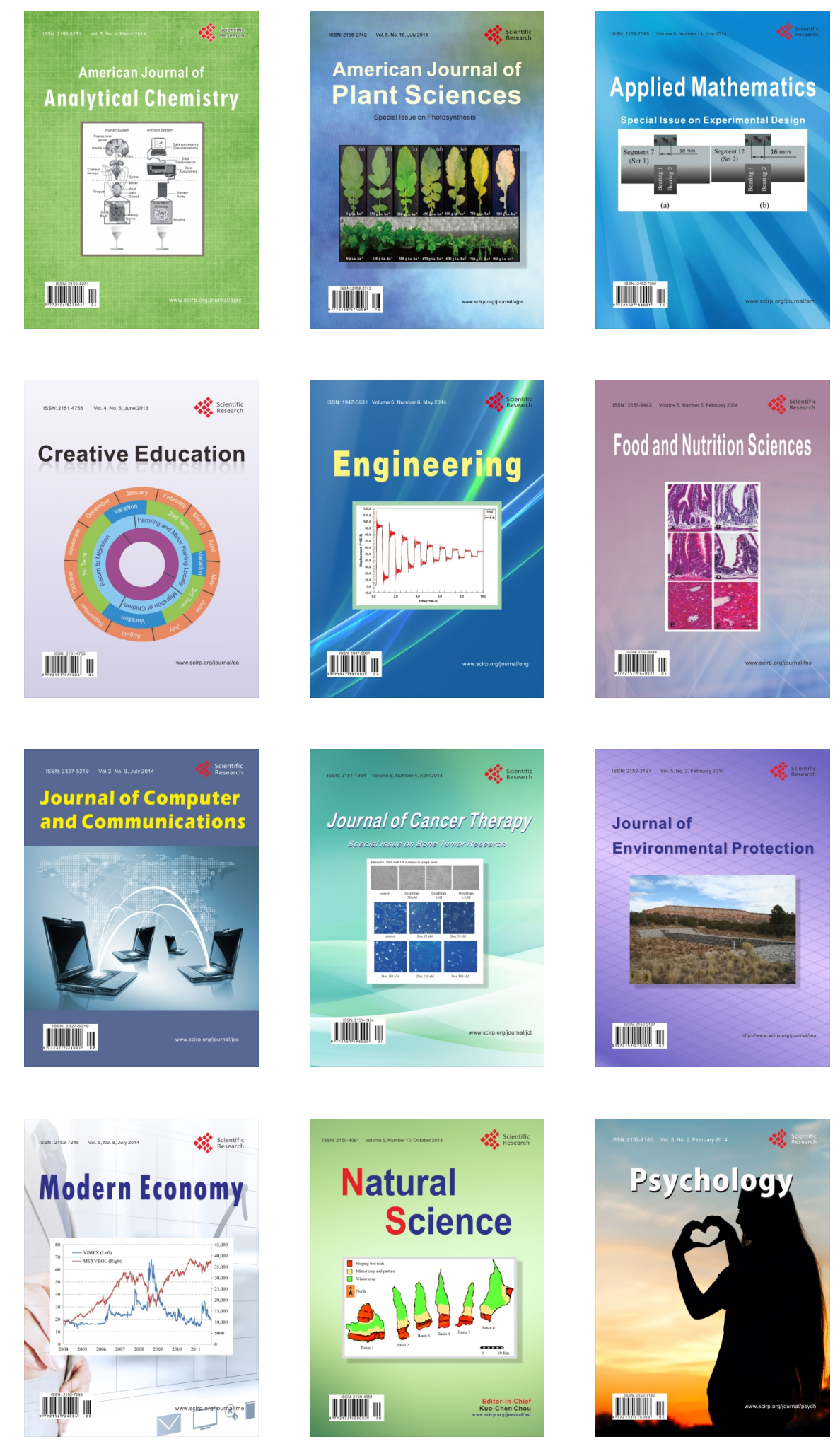